\title{
ISOCRATES AND PHILOSOPHY IN DIONYSIUS OF HALICARNASSUS' RHETORICAL WRITINGS
}

We saw in the previous chapter that Lysias had a foundational role in Dionysius' critical work. Isocrates is another crucial pillar in Dionysius' rhetorical edifice, whose influence extends primarily to his treatment of the educational and philosophical components of rhetoric. Isocrates' importance for Dionysius has long been acknowledged and Dionysius himself is very explicit about it. He gives the clearest account of the Isocratean flavor of his program in his Isocrates, which is the second essay of the collection On the Ancient Orators. The structure of Isocrates is very similar to the previous work of the collection, Lysias, but in the course of the essay it becomes increasingly clear that Dionysius' emphasis and interest in the orator are visibly different from the stylistic concerns which were such a prominent feature of the first essay. ${ }^{I}$ Dionysius sets up a new image of Isocrates, determined to show that he is not merely another orator on the list. We will see that Isocrates becomes a representative of the novel vision of education and rhetoric advocated by Dionysius and tailored to the particular political context of first-century BCE Rome.

On the one hand, it is clear from Isocrates' works, from the topics and the style in which they are treated, that he was not just another speechwriter. As we noticed before, his reception too, up until the first century $\mathrm{BCE}$, had primarily emphasized the political and philosophical aspects of his work, though the philosophical dimension had not received much detailed attention. He was primarily regarded as in opposition (and inferior)

\footnotetext{
I Bonner (I939) treats the two essays as fundamentally similar in structure and outlook, except that Isocrates falls short in some of the categories where Lysias excels. Bonner also points to the development of the critical method in this essay, where Dionysius goes into more depth in his analyses of the style of a particular author.
} 
to other philosophical schools. On the other hand, Isocrates had made significant contributions to writing and style, eventually also becoming firmly fixed in the canon of ten orators. ${ }^{2}$ Hence, despite his continued relevance for Greek paideia, Isocrates remained in-between rhetoric and philosophy and was - for all the reasons discussed in previous chapters - not a mainstream author, neither for the philosophers nor for the orators. One of the contributing reasons for such an assessment might have been Plato's Phaedrus, which also casts Isocrates famously as somewhere in-between rhetoric and philosophy. Similarly to his essay on Lysias, where Dionysius was in constant dialogue and competition with Plato's Phaedrus and its evaluation of Lysias' style, so too we see an underlying influence of the Phaedrus in Dionysius' essay on Isocrates. As a response to Plato and other critics, Dionysius' innovative approach to Isocrates lies in bringing him to the center of his rhetorical pedagogy and celebrating Isocrates' work as 'true philosophy'. His emphasis on the practical aspects of Isocrates' philosophy might also suggest that he was aiming to appeal to the tastes of his Roman students and readers.

\section{I Dionysius' On Isocrates}

Dionysius' essay on Isocrates is thematically divided into three parts: the long first chapter lays out Isocrates' life and summarizes his influence on rhetoric and philosophy, the second part (chapters 2-I4) reviews the stylistic and thematic strengths and weaknesses of Isocrates' discourses, and the third part (chapters I 5-20) quotes and discusses two examples from Isocrates' speeches. The structure of the essay, then, is similar to Dionysius' previous essay Lysias and, furthermore, Lysias remains the most important figure of comparison for Dionysius' discussion of Isocrates throughout the essay.

\footnotetext{
2 On the notion of 'canon' (kav'sv), see Pfeiffer (I968), 207. For the canon of ten Attic orators, see Worthington (1994) and O'Sullivan (I997), who advocate a first-century BCE date. For earlier dates of the canon, see Smith (I995); for later dating, Douglas (I956).
} 
This supports a reading suggested above that the two works were intended to be complementary.

However, a few interesting details and divergences from Lysias immediately stand out in this essay. Firstly, compared to the biographical section of Dionysius' essay on Lysias, which was very brief and primarily focused on laying out the breadth of Lysias' writings, in this essay Dionysius takes time and space to inform the reader in more detail about Isocrates' life and teachings. It is not surprising that he relies in this section heavily on Isocrates' own writings, in which references to his position, career and mind-set abound. As Wiater notes, 'Dionysius adopts the self-image Isocrates created in his writings', ${ }^{3}$ and given the wealth of such information available, Dionysius appears to make use of this information as widely as possible. ${ }^{4}$ There might be, however, more to this biographical interest than first meets the eye. Isocrates' self-presentation is closely connected to his overarching message, repeatedly expressed in his discourses, that philosophy is not about theoretical quibbles and technical talk, but rather about making good decisions for the community and about how to reach those. Spending time on setting out in laudatory terms the kind of person, teacher and philosopher Isocrates was, is also time spent on preparing his readers for the kind of teaching and philosophy that Dionysius himself is striving towards. 5 There is a marked contrast, therefore, with his evaluation of Lysias, who is expected to give the tone and perspective for a good rhetorical style. Isocrates and Dionysius will provide the substance.

From Isocrates' biographical details, Dionysius highlights the following as particularly important: his Athenian identity

3 Wiater (20I I), 68.

4 Some other examples where Dionysius makes use of Isocrates' own concepts or selfdescription to characterize the rhetorician are discussed in Too (I995), 29-35, 76-7.

5 Cf. Wiater (20 I I), 7I. Dionysius' approach to Isocrates' biography seems to be thus connected with the importance of the lives of ancient (philosophical) authorities that start serving a separate function as educational models. To my knowledge, no other ancient author before Isocrates (and in fact very few after him, too) spends so much time in their works talking about themselves. I hope to address this topic elsewhere in more depth. 
and family background (I.I), early education and interests in philosophy and politics, his intellectual influences in both philosophy and politics (I.I-2), the important themes that characterize Isocrates' work (I.3), and the influence of his work in his own time (I.5). According to Dionysius, Isocrates was the first to turn rhetoric away from eristics and

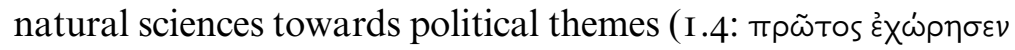

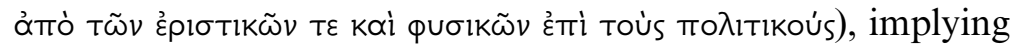
that Isocrates' approach was followed by later rhetoricians. Isocrates was an influential teacher and intellectual and his students were successful in a variety of fields (forensic orators, politicians, historians); Dionysius concludes that Isocrates had made his school a symbol of the Athenian polis (

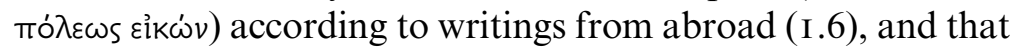
he was most successful in making money out of philosophy

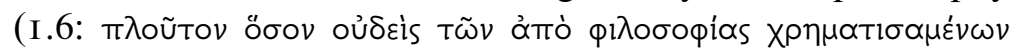

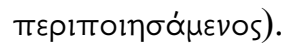

Many of these claims need unpacking and some of this explanatory work, especially in relation to Isocrates' contributions to conceptualizing Greek identity and its special appeal to Dionysius, has been undertaken in more recent scholarship. Hidber, for example, has recognized Isocrates' influence on Dionysius in the following areas: the use of antagonism between 'us' and 'them' (in Isocrates primarily shaped as a contrast between the Greeks and the barbarians), the idea of good education as being based on cultivating the ability to write good prose, and the idea of broad education as philosophy that prepares his followers/students for public life (political career). ${ }^{6}$ Wiater has mostly focused on Isocrates' influence on Dionysius' conception of the classical or classicizing identity. ${ }^{7}$ While the focus of these previous studies has been primarily on Dionysius' use of Isocrates for laying out his classicizing program, the aim of the following analysis is to look closely at the way in which Dionysius aims to create a coherent rhetorical tradition, where Isocrates is treated as a

\footnotetext{
6 Hidber (I996), 5I.

7 Wiater (20I I). This is also the primary topic of Goudriaan (I989).
} 
visionary tasked to lay out the ethical limitations and possibilities of rhetoric.

One cannot fail to notice Dionysius' downplaying of Isocrates' distinctive style in the essay. This is also noticeable from the fact that in the second part of the essay (2-I4), Dionysius spends only two chapters talking about style before turning to content. It is clear that Isocrates is important for Dionysius for what he says, but not how he says it. Isocrates famously advocated the idea that good prose is a sign of education or $\pi \alpha \delta \delta$ sia, an idea that resonates strongly in Dionysius' writings. ${ }^{8}$ Yet, Dionysius' position on Isocrates' success in prose style is ambivalent: while acknowledging Isocrates' contribution to raising awareness of the importance of good written self-expression and making this idea one of the central points of his 'philosophical' school, Dionysius has at the same time few good words to say about Isocrates' own style. Chapter 2 of the essay, which is dedicated to a quick comparison between the styles of Lysias and Isocrates, presents Dionysius' criticisms of Isocrates' style: Isocrates' style is

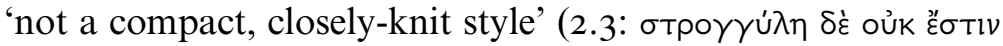

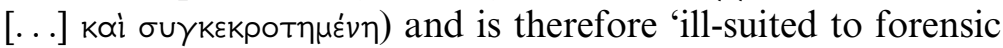

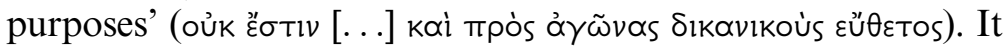

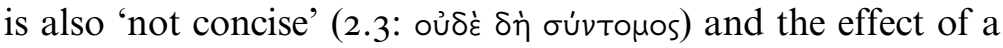
ceremonious and ornate dignity may at times be more attract-

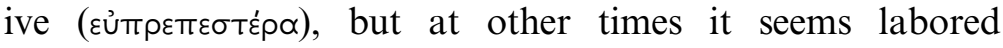

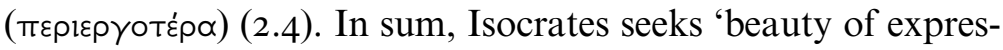
sion ( $\left.\varepsilon \cup \varepsilon^{\prime} \pi \varepsilon 1 \alpha\right)$ by every means, and aims to express himself in a

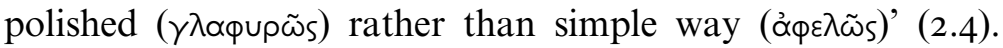
Finally, Isocrates uses the rounded period and strong rhythms (overusing the Gorgianic figures), all of which assimilate his prose to verse and thus render his work 'more suitable for

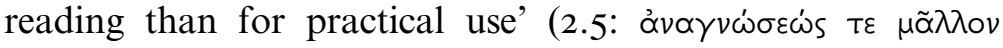

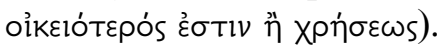

Dionysius' criticism of Isocrates' style is characteristic of Isocrates' reception (both ancient and modern) and 


\section{Dionysius' On Isocrates}

Dionysius points out that he is not the first to voice disapproval of Isocrates' prose. He introduces the views of previous critics in Chapter I3, just after having given a brief overview of his own criticisms of Isocrates' style, and claims that: 'This judgment of mine is not, of course, original: many earlier critics have held the same view regarding Isocrates' (I3.I:

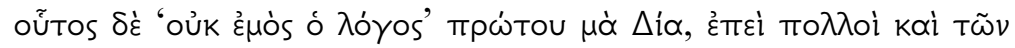

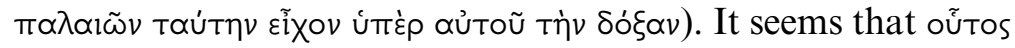
picks up a particular criticism of Isocrates' style and most probably is a reference to the unsuitability of Isocrates in an actual court or assembly hearing that Dionysius had discussed previously. ${ }^{9}$ That this is the case is confirmed by the quotations of critics that Dionysius introduces later on in the same chapter: Philonicus the grammarian complains that there is no accordance between the characters and their language (I3.2), Hieronymus the philosopher claims that Isocrates' speeches are unsuitable for declamation (I3.3), and many others critics hold similar views (13.5). Dionysius agrees and evokes examples of Isocratean prose that confirm these opinions (I3.6). Even though Dionysius acknowledges the fact that Isocrates' speeches were not intended for public delivery in the courtroom (I.2), his occasionally scathing criticism of Isocrates' style betrays how tiresome his prose must have seemed to him as well. When introducing his own extended discussion of Isocratean style, Dionysius warns the reader to disregard Isocrates' overuse of stylistic features criticized above, because they will not be appropriate to imitate for court speeches, and advises them to focus instead on other qualities (тoĩs $\alpha \lambda \lambda$ ors). Presumably he means the subject matter and how Isocrates 'shows that justice is superior to injustice not only on

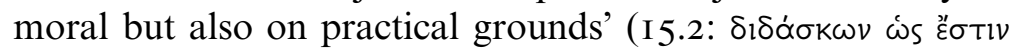

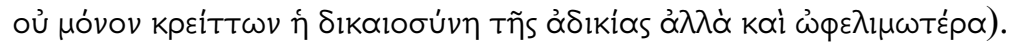
In short, critics who are looking for models in courtroom rhetoric have rightly advised against following Isocrates' style.

${ }^{9}$ Goudriaan (I989), part I discusses the broader political background of the time and argues that due to the contemporary political scene Dionysius is more focused on assemblies and the courts. 
Dionysius suggests, however, that style and content can be kept apart and that Isocrates should be on everyone's minds for the latter aspect.

Is such a reading of Isocrates not undermining the unity of his teaching and thus misrepresenting his contribution? Indeed, Dionysius' criticism of an author who has championed the notion of kaipós as one of the driving forces of his philosophy, education and prose, for lacking in good judgement in the very things that he teaches (i.e. good prose) seems to require further explanation. To be sure, Isocrates' speeches convey the sense that his prose works are an expression of the content of his teachings, and that the two can hardly be separated. ${ }^{\text {IO }}$ That is, Isocrates' refined, carefully composed and long-winded sentences explicitly downplay the importance of an effective performative style and instead draw attention to the writerly character of his works. Isocrates, by emphasizing in his writing the very skills of good and sophisticated prose compositions and appreciating this ability as a sign of good paideia, which stands in the center of his educational program, makes no suggestion that one could distinguish his views on good prose from their content. Dionysius, however, appears not to see this problem; for him, Isocrates is essentially a ceremonial writer, whose writing will bear recitation at formal events or be studied privately (2.6): he does not belong in the courtroom and is

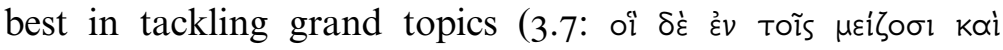

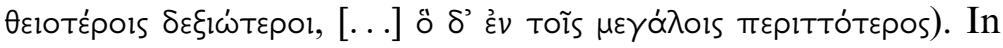
Dionysius' own words: 'most important is the scope of his discourses that he concentrated on and the nobility of the subjects upon which he chose to concentrate' (4.2: $\mu$ ó $\lambda_{1} \sigma \tau \alpha \delta^{\prime}$

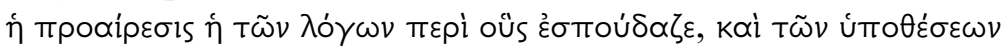

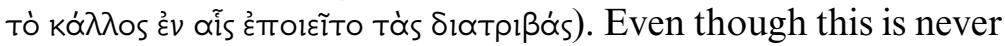
spelled out in his essays, Dionysius seems to regard a broader intellectual vision and good moral preparation essential for a successful demonstration of rhetorical mastery. In other words, Isocrates' words are not for imitation (nor were they

ro On the interconnectedness of Isocrates' prose and thought, see above, chapter 3.2. 


\section{Dionysius' On Isocrates}

so intended probably also for his own school in the fourth century $\mathrm{BCE}$ ), but for reflection and general improvement of character. In this sense, by constantly reminding his readers of the appropriate context for different kinds of rhetoric, Dionysius' distinction between Isocrates' style and philosophy seems more justified.

In sections 5 to 9 of the essay, Dionysius gives a list of the kinds of virtues or grand topics that one can find in Isocrates, with a brief summary of the speeches where he finds these notions advocated. In terms of the structure of the essay, this list is construed as a parallel to the kinds of stylistic virtues that Dionysius explored in his previous essay on Lysias. According to Dionysius, Isocrates' Panegyricus can be read as an exhort-

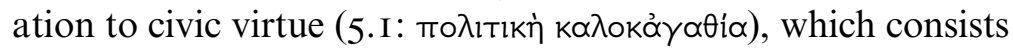
in being prudent (5.2: $\sigma \omega \dot{\varphi} \rho \omega \nu)$, prioritizing concern for the common good over personal advantage (5.2: oi $\gamma \varepsilon \tau \tilde{\omega} \nu \mu \dot{\varepsilon} v$

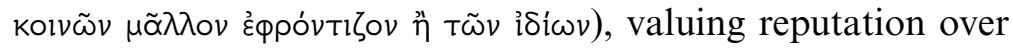

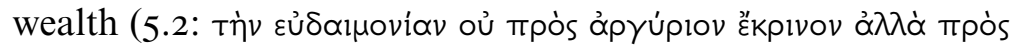

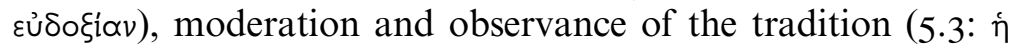

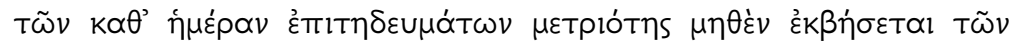

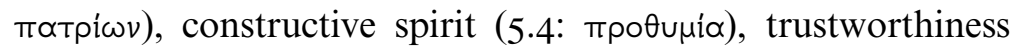

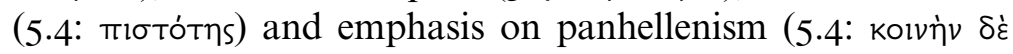

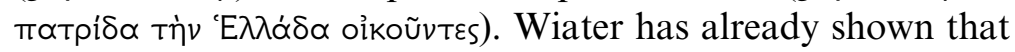
in summarizing the speech Dionysius is essentially relying on a very small selection of passages from that speech and has accommodated them to his own program as expressed in $O n$ the Ancient Orators, and that this is the method he adopts throughout the sections. II Isocrates' Letter to Philip should delight, according to Dionysius, anyone who is in a position of

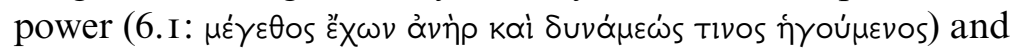
teach about the superiority of Greeks; his On the Peace should be read as an exhortation to justice and piety in international

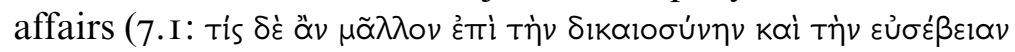

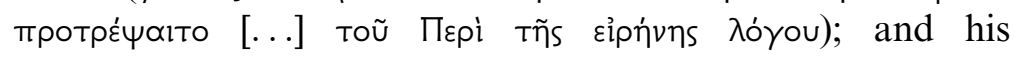
Areopagiticus as an encouragement to get responsibly involved

I Wiater (20II), 7I-4. 


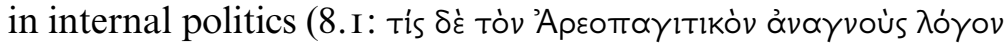

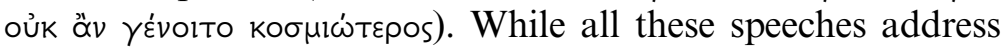
overlapping virtues that Dionysius mentions as the central theme of the Panegyricus, по of speeches also seems to characterize neatly and summarize Dionysius' interests: civic education (as portrayed in the Panegyricus), importance of Greek and Greekness (as expressed in the Letter to Philip), virtues involved in imperial politics (as laid out in On the Peace) and responsible civic action in internal politics (on the model of Areopagiticus). If this is a correct way to read Dionysius' priorities in introducing these speeches, then this is further evidence for reading Dionysius as deeply rooted in his contemporary political scene and tailoring his 'classicising identity' (in Wiater's words) to his Roman audience and their current political needs. ${ }^{\text {I2 }}$

If indeed Dionysius is interested primarily in Isocrates' philosophy, why does he continue spending time on analyzing his style and criticizing it? Indeed, he is far more explicit about Isocrates' stylistic shortcomings than about laying out in more detail his philosophical content and rhetorical virtues. This could be related to what Damon suggests about Dionysius' critical methodology, that Dionysius' essays demonstrate the common asymmetry of judgement: it is far easier to describe the faults than to give as detailed an account of the virtues of a writer. ${ }^{\text {I3 }}$ But it might also be the case that Dionysius' 'failure' to go deeper in his explorations of the particular virtues of Isocrates' work stems from his programmatic lack of interest in the more theoretical discussions on education, oratory and philosophy, at least for the purposes of the project he had set himself in the preface to On the Ancient Orators. Instead, with his general and impressionistic praise of Isocrates, Dionysius gives his readers a rough idea of the kind of 'useful' philosophical

${ }^{12}$ Cf. Gabba (1982).

${ }^{13}$ Damon (I99I), 49-52. She applies this, rightly so, to stylistic criticism only and it is not obvious (in fact it seems counterintuitive) that the asymmetry of judgement would also apply to philosophical discussions. 
rhetoric he has in mind. ${ }^{\mathrm{I}}$ It is not the kind based on theoretical discussions of abstract matters, but rather the kind which appears to bring about a change in the listener's character or mind-set simply by appealing to themes that are of seminal importance: war, peace, good life, education and so on. Interestingly, and perhaps not at all surprisingly, the impact that he seems to envision for this Isocratean philosophical rhetoric comes rather close to his ideas of Lysianic xópıs: through reading and studying of Isocrates' work one cannot but come to realize the importance of these virtues and - having internalized them - employ them in one's own political or writerly career. There is no need to linger on these virtues at great length (as there is no point in trying to get theoretical about how to achieve xópls) for this is something that seems to happen to the readers of Isocrates almost instantaneously: tís oủk å $v$ ývoolto (8.I)... Or at least, this is the effect Isocrates' works will have on well-instructed students who have been exposed to these topics for a prolonged time. These brief introductory expressions of admiration for Isocrates' discourses are well in line with Dionysius' rhetorical program in which he assigns primary attention to the imitation of classical models and rejects the view according to which one could gain rhetorical insight from technical workbooks on the topic alone. ${ }^{\mathrm{I} 5}$

Despite the fact that Dionysius eschews any more detailed engagement with philosophy, he refers to philosophy and related fields often enough to justify a further exploration into his philosophical commitments and positions. Isocrates is, after all, initially introduced in the biographical section as a

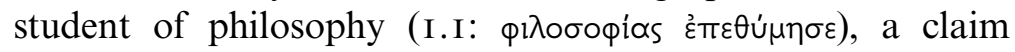
qualified in the next sentence by a reference to Isocrates' teachers, Prodicus, Gorgias and Tisias. The ancient philosophical tradition links these three figures primarily, or even solely, to rhetoric and sophistry rather than to philosophy, surely as a

${ }^{14}$ Of course, appealing to to Xpírıov is the standard aim of the educational tradition, but it might have a particular ring in the Roman context and among the Roman audience who are notoriously suspicious of Greek philosophy and theory.

${ }^{15}$ Cf. Dionysius' First letter to Ammaios 2.3. Goudriaan (1989) describes Dionysius as a 'dynamic writer' (I4-I6) and claims that he distances himself from technocratic writings (I7). 
result (at least partly) of Plato's negative portrayal of sophists in his dialogues. ${ }^{\text {I6 }}$ When Dionysius calls Isocrates' training 'philosophical' and appeals as evidence for this claim to figures who have been employed by Plato precisely to specify what philosophy (as Plato construes it) is not, Dionysius appears to signal from very early on in the essay that his conception of rhetoric and philosophy will be provocatively different from that used in the philosophical schools. Furthermore, it is not a random list of sophist-philosophers that Dionysius refers to here. Indeed, when Dionysius constructs an intellectual ancestry for Isocrates' philosophical thought he is using three sophists who all have been traditionally linked with each other through a teacher-pupil relationship: Tisias was arguably Gorgias' teacher, ${ }^{\mathrm{I}}$ and according to several ancient accounts Gorgias was a teacher of Prodicus. ${ }^{18}$ Ancient accounts that look back at the emergence of rhetoric and rhetorical theory consider Tisias one of the principal contributors (together with Corax) to this movement. ${ }^{19}$ By tracing his intellectual lineage all the way back to Tisias, ${ }^{20}$ Dionysius not only challenges the concept of philosophy, but he also creates a sense of a continuous school of thought around Isocrates, thus lending his ideas a more ancient and authoritative aura. It was well known that Isocrates had officially set up in Athens a school of philosophy, but - since it never had succession like the Academia and the Peripatos - it eventually died out as a school after the death of Isocrates. Dionysius here connects Isocrates to thinkers who were active before philosophy became a fixed concept and

${ }^{16}$ For attempts to recover the intellectual heritage of the sophists, see Kerferd (I98I) and de Romilly (I992).

${ }^{17}$ See further de Romilly (1992), 58-60.

${ }^{18}$ For a good overview of Prodicus' biographical data, with ancient testimonia, see Mayhew (20II). In the Suda, Prodicus is claimed to have been the student of Protagoras, but there is also a parallel tradition associating him with Gorgias. There is another interesting aspect sometimes emphasized in Prodicus' biographies, namely that he had a deep voice which made what he said quite unintelligible (Plato Protagoras 315c-I6a). As has been noted, this is ironic given that Prodicus was famous for his insistence on the clarity of words.

19 Cicero Brutus I2.46, attributing this view to Aristotle.

${ }^{20}$ Isocrates would of course not have been pleased about being fashioned as a pupil of these 'older sophists'; cf. Against the Sophists I9-20. 


\section{Dionysius' On Isocrates}

therefore reinforces the idea that Isocratean philosophy is 'true philosophy' because it goes back to the earliest thinkers in Greece.

It is also significant that Prodicus, Gorgias and Tisias were famously known for having gathered substantial wealth through their teachings. ${ }^{2 \mathrm{I}}$ Plato is one of the main sources for this perception, but it is also confirmed by Isocrates who claims in his Antidosis ( I55), for example, that of all sophists Gorgias made most money from teaching. Be that as it may, by Dionysius' time it might have been commonplace to regard the activity of ancient sophists as a lucrative business, ${ }^{22}$ all of which makes it even more curious that Dionysius is evoking the trio with all their heavyweight sophistic connotations as philosophical teachers of Isocrates. Furthermore, Dionysius then goes on to say that Isocrates himself made most money

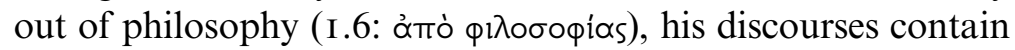

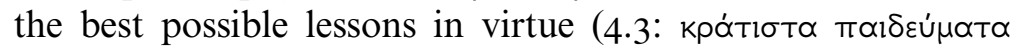

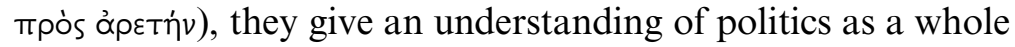

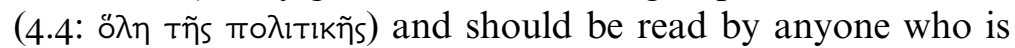

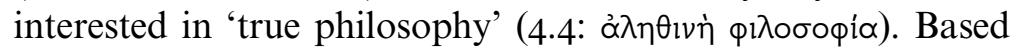
on this description, Dionysius appears as a careful reader of Isocrates and eager to amplify the provocation that the latter had introduced for his contemporary philosophical schools and intellectuals. ${ }^{23} \mathrm{We}$ should also note that Dionysius never mentions Socrates as an influence on Isocrates. It may not be too far-fetched to suggest, then, that Dionysius reiterates Isocrates' challenge to contemporary educational models and scholastic philosophical schools.

There is another noteworthy aspect to Dionysius' mentioning precisely these three names as Isocrates' teachers rather than any other famous ancient rhetoricians. We have already

${ }^{21}$ Prodicus is credited, for example, in a scholium to Aristophanes' Clouds 36 Ia with having been the first to introduce a 'fifty-drachma epideictic speech' ( $\pi \rho \tilde{\omega}$ Tos $\delta \dot{\varepsilon}$

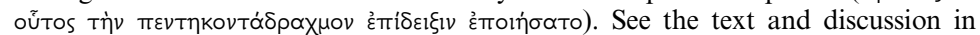
Mayhew (20II), 74. Isocrates also refers to these 'older sophists' as 'professors of

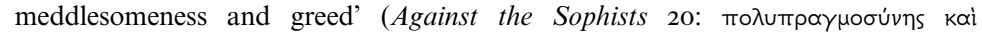

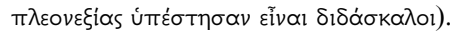

${ }^{22}$ It certainly seems to be the case by the time of Dio Chrysostom; cf. speech 54 .

${ }^{23}$ For Isocrates' provocation to Socratic schools, see above, Chapter 4. 
noted the specifically anti-Platonic flavor of these first paragraphs of the essay, and this impression becomes even stronger if one considers that the only other place where these three names are evoked together is Plato's Phaedrus $(267 \mathrm{a}-\mathrm{b}) .{ }^{24}$ In this passage, Socrates gives a list of sophists who have composed handbooks of rhetoric and whom Phaedrus considers teachers of rhetoric. He then brings out (in mocking tone) in each case what are commonly perceived to be their contributions to rhetoric. Tisias and Gorgias are credited with the invention of giving more weight to probabilities over truth, of making the small appear great by the power of their words, and of having introduced 'conciseness of speech and measure-

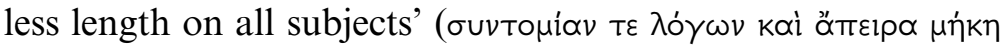

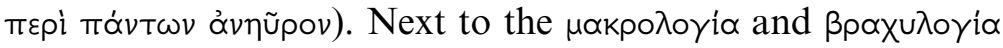
of Tisias and Gorgias, Prodicus is mentioned as an innovator

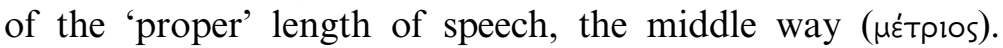
Socrates' sarcastic tone when listing the famous sophists who claimed to have made advances in the art of rhetoric leaves no doubt that this constitutes a re-evaluation of these writers. Indeed, somewhat later Socrates recategorizes them as contributors to the preliminaries of the art but not to art itself (268e-9a). When Dionysius maintains, in contrast, that Tisias, Gorgias and Prodicus taught Isocrates important philosophical insights (about rhetoric?), he goes not only against the standard philosophical tradition which had considered the trio sophists, but against this passage in the Phaedrus specifically. For while Dionysius suggests that (at least some of) the philosophical core of Isocrates' works goes back to his philosophical studies under Tisias, Gorgias and Prodicus, Plato denies them any place in the art of rhetoric, not to mention in philosophy.

Is it possible that Dionysius simply misunderstood the Phaedrus and is evoking it to support his interpretation even though the dialogue itself, when read closely, suggests a

${ }^{24}$ Gorgias and Prodicus are often referred to together (e.g. Meno 96d, Apology I9d), but there are very few references to Tisias, also outside of the Platonic corpus. 
different kind of reading? ${ }^{25}$ We have seen before that Dionysius opts for a superficial reading of the characters' claims and does not consider the possibility of irony (e.g. in the evaluation of Lysias or the praise of Isocrates at the end). This is possible, though I consider it rather unlikely. Dionysius' ambivalent attitude to Plato, particularly to the latter's competence as a stylist and a critic of style, suggests that Dionysius does have the ability to critically engage with the text. I think it is more likely that Dionysius goes against Plato and Plato's authority deliberately. This would bring about two possible reactions: for those who know their Plato, Dionysius appears a provocative author who is undertaking a criticism of the most influential text published thus far on the rhetorical tradition - the Phaedrus. For those who are not familiar with the complexities of the rhetorical and philosophical tradition (especially for Dionysius' students), Dionysius appears to reinforce ideas presented there and is thus able to demonstrate his intimacy with the characters and terminological details of this powerful dialogue.

All in all, Plato's Phaedrus appears to frame Dionysius' discussion of Lysias and Isocrates and it is certainly a work with which Dionysius is closely, if antagonistically, in dialogue. ${ }^{26}$ That Dionysius is a close reader of Plato's Phaedrus, and emphatically regards Isocrates as the representative of 'true philosophy', prompts further questions about his conception of philosophy and the way it is treated elsewhere in his critical works. In On the Ancient Orators, for example, Dionysius describes the overall motivations for his critical project and suggests there that the work is intended primarily for 'those

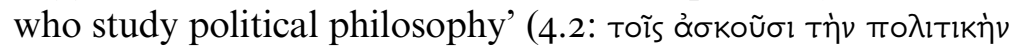
$\left.\phi \imath \lambda \circ \sigma \circ \phi_{i \alpha}\right)$. We will briefly investigate what exactly that means and to what extent Isocrates is a guiding figure for such 'political philosophy' throughout Dionysius' critical works.

${ }^{25}$ I would like to thank Harvey Yunis for prompting me with this important question.

${ }^{26}$ This is, of course, also clear from Dionysius' use of the Phaedrus in his essay on Demosthenes. 


\subsection{Dionysius on True Rhetoric, True Philosophy and True Isocrates}

With regard to his views on rhetoric and philosophy, Dionysius does not seem to be a follower of any one particular philosophical school. Instead, it has been argued that Dionysius draws on a variety of philosophical schools, such as the Stoics (especially in grammar), Peripatetics and that he has a close familiarity with Plato. ${ }^{27}$ In his essay on Isocrates, Dionysius provocatively associates his interests in Isocrates with what he calls 'true' philoso-

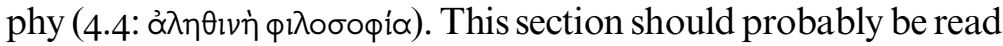
side-by-side with the opening sections of On the Ancient Orators,

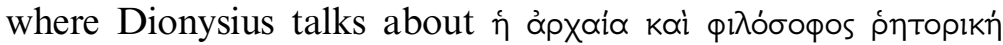
(I.2) - an ancient philosophical rhetoric - which, given the intense debates of the fourth century ВCE (at least as recorded in Plato, Isocrates and Aristotle) on the complicated relationship between philosophy and rhetoric, might seem rather controversial, or at least require further explanation. As mentioned above, this combination of philosophy and rhetoric vividly evokes Plato's views on this matter in the Phaedrus which has already been suggested to play a more general and in a way fundamental role in evaluating the aims of Dionysius' critical essays. Dionysius does seem to take up Plato's challenge of developing a 'philosophical rhetoric', but, instead of joining rhetoric with (Platonic) metaphysics, Dionysius weaves political and ethical philosophy into current practices of rhetoric. Indeed, there is something deeply un-Platonic in Dionysius' understanding of this kind of philosophical rhetoric as the starting point, rather than a distant and perhaps unachievable goal (as in the Phaedrus), of a rhetorical or philosophical enterprise. While the Phaedrus begins with rhetoric and moves slowly to a different, philosophical, conception of the art, Dionysius proposes philosophical rhetoric almost as a generally understood or common notion requiring no further explanation.

${ }^{27}$ See de Jonge (2008) on Dionysius' engagement with the Stoics, and Bonner (I938), Wooten (I994) and Fortenbaugh (2005), I4-I7 on Dionysius' Peripatetic inclinations. Plato is, after Demosthenes, the second most quoted name in Dionysius' oeuvre. 
Another controversial, and arguably anti-Platonic, aspect that Dionysius brings up in relation to Isocrates and his practice of philosophy is money. ${ }^{28}$ This topic was briefly touched upon above in the analysis of Dionysius' use of Tisias, Gorgias and Prodicus as Isocrates' philosophical models. It seems that ever since Plato's dialogues, where sophists' lucrative practice of 'selling education' was subjected to profound criticism with long-lasting effect on subsequent generations, ${ }^{29}$ material wealth had been strongly disassociated from (teaching) philosophy. Amongst different philosophical schools, Isocrates had always been the exception who did not criticize his contemporary sophists for taking money, but suggested that they were taking too little! ${ }^{30}$ To judge by the way in which Dionysius emphasizes and applauds Isocrates' financial success through his philosophical activities, it is clear that Dionysius has a rather un-Platonic position on this aspect of education and philosophy, and he openly turns to Isocrates, Plato's rival, as a model for an intellectual as well as a financial success story. ${ }^{3 \mathrm{I}}$ But what exactly does this emphasis on financial success mean in the context of Dionysius' essays? Perhaps nothing less than challenging the position and role of philosophy in his contemporary environment and, through the figure of Isocrates, sketching out another way to see philosophy as practical and meaningful for the social and political surroundings. Hence, Dionysius does not turn to Socrates when in search of alternatives, for Socrates is claimed as the fountainhead for most philosophical schools of the time, but rather to Isocrates. In fact, Dionysius mentions Socrates only as a character in Plato's dialogues, or makes use of 'Socratic' as a generic term for writers of Socratic dialogues ( $\Sigma \omega \mathrm{kp \alpha t \imath koi}$ $\lambda o ́(0) .{ }^{32}$ Dionysius does not refer to Socrates' engagement

${ }^{28}$ On Isocrates' relationship to money and philosophy, see above, Chapter 4.

${ }^{29}$ Perhaps most famously in Plato's Sophist 223a.

${ }^{30}$ E.g. Isocrates' Against the Sophists 3-6.

${ }^{31}$ Cf. Letter to Gn. Pompeius for Dionysius' further critical remarks on and engagement with Plato.

32 Socrates as a character in Plato's Phaedrus: Demosthenes 7. For references to and discussions of Socratic writings see, for example, Demosthenes 6 and 23 (Plato the Socratic), CV Io (Xenophon) and I6 (Plato the Socratic), and Thucydides 5I. 
with Athenians or his influence on moral philosophy. Moreover, it seems that the image of the impoverished Socrates that became an important inspiration for the conception of a (true) philosopher carries little weight with Dionysius, whose turn to Isocrates, one of the wealthiest Athenians of the time, clearly signals a highly polemical attitude towards this kind of philosophical tradition. Dionysius is instead attracted to Isocrates who stands for an intellectual who values rhetorical education with its emphasis on language and writing, who has a stake in politics and considers active participation in actual decision-making as one's civic duty, and finally who has a respectable standing in society due to ample financial means, thus giving intellectuals the (political) authority needed to promote culture and education. This image of a rich Isocrates might have struck the wealthy Roman patrons as an attractive model of an intellectual. Indeed, these are the same patrons who would presumably send their offspring to be taught by Dionysius.

In his critical essays, however, Dionysius is cautious with terminology, and it might seem as if his references to philosophy do not bear out this provocative reading sketched out above. Looking at Dionysius' (explicit) engagement with the

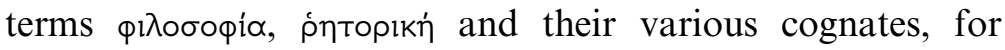
example, it appears that despite the fact that Dionysius claims Isocrates to be the proponent of 'true philosophy' ( $\alpha \lambda \eta \theta_{i v} \dot{\eta}$ $\left.\phi i \lambda \circ \sigma \circ \phi^{\prime} \alpha\right)$, in his essay Isocrates he most often describes him with the noun rhêtor ( $\rho \dot{T} \tau \omega) .{ }^{33}$ Dionysius seems to have considered $\rho \eta \dot{\tau} \omega \rho$ the most appropriate label for Isocrates, as he uses this often (as a stylistic device) to avoid repeating Isocrates' name (e.g. 8. I, 9. I, 20.5). In fact, the word 'philosopher' ( $ф \lambda \lambda_{\text {ó } \sigma \circ ф \circ \varsigma)}$ is used once in the essay as an epithet and in this case to denote somebody else: in Chapter I3 where Dionysius introduces the positions of previous critics on the style of Isocrates, he claims that Hieronymus the philosopher

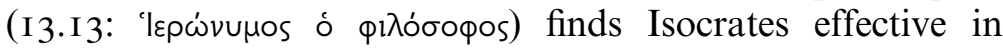

33 E.g. 3.7 (twice), 4.4 (twice), 8.I, 9.I, I5.I, 20.5. 
True Rhetoric, True Philosophy and True Isocrates

reading but unsuccessful when delivered. What is interesting about this sentence, aside from its comparison with Isocrates, is the reference to a philosopher who is actually reading Isocrates' works and assessing them on the grounds of their 'performability'. In the same essay, on another occasion, Dionysius goes as far as to contrast Isocrates with philosophers. When commenting on Isocrates' speech Archidamus, Dionysius claims: 'I would certainly say that Isocrates was giving this advice not only to the Spartans but also to other Greeks; and for all men it is much more effective advice than that given by all those philosophers who make virtue and

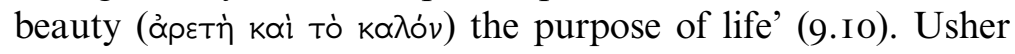

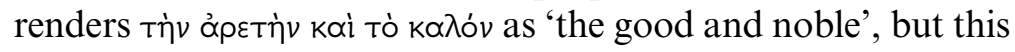
might obscure Dionysius' point. For Dionysius is presumably not saying that Isocrates is uninterested in 'the good' as the goal of life; he seems instead interested in drawing attention to the distinction between the immediate and pragmatic on the one hand, and the general and valuable in itself on the other. $\mathrm{He}$ is praising Isocrates for giving clear pragmatic advice to the Spartans and everyone on how to act in particular circumstances, and Dionysius suggests that in these circumstances (when decisions regarding war are made) this kind of advice is to be preferred to the more general and vague discussions of the philosophers. This comparison gives us significant information about Dionysius' opinion of philosophers, and gives some hints about why Isocrates is not associated with the фı $\lambda$ óooфor. ${ }^{34}$ The so-called philosophers are simply useless characters and calling Isocrates by that name would obscure his potential contributions.

Yet, while Isocrates himself is not awarded the 'title' of a

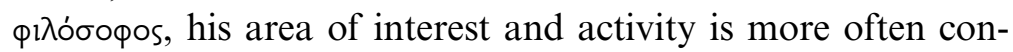
sidered by Dionysius as philosophy. We see this shifting focus, for example, in the very first chapter of the essay, where Isocrates is described as being attracted to the study of phil-

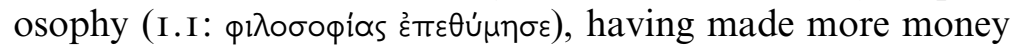

${ }^{34}$ Isocrates the rhetor is also contrasted to Plato the Socratic philosopher in Demosthenes 3.2. 


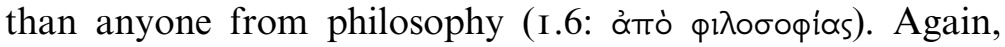
Dionysius suggests that anyone interested in 'true philosophy'

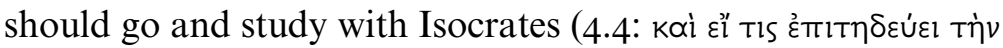

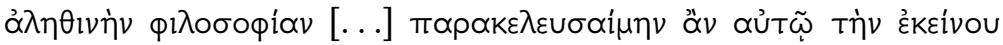

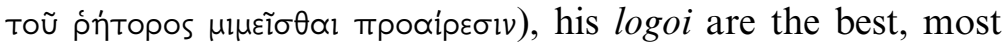

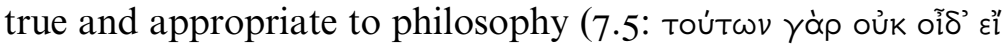

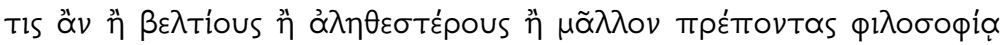

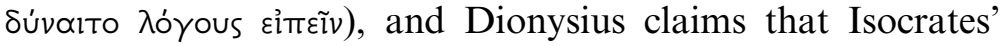
'philosophical purpose' is superior to everyone else's (I 2.2: tò

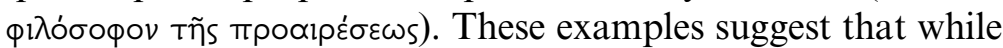
Dionysius deliberately avoids calling Isocrates a philosopher, he is at the same time happy to refer to Isocrates' activity and works as philosophy. This is in line with Isocrates' own conception of his practice, for he too avoided openly calling himself a philosopher, and instead made claims about philosophy. ${ }^{35}$

But what does Dionysius mean when he talks about 'true philosophy'? What kind of opposition is he setting up with this insistent emphasis on 'true' (as opposed to 'false'?) philosophy? Is 'true' here simply another way to say 'better' or 'more accurate'? Dionysius makes no attempt to clarify this usage and, interestingly, in his preface to On the Ancient Orators he never uses this adjective ('true' or 'truthful', $\alpha^{\lambda} \lambda \eta \theta$ '่ or ờ $\lambda \eta \theta v v$ ós) to characterize the subject of his work, 'the ancient and philo-

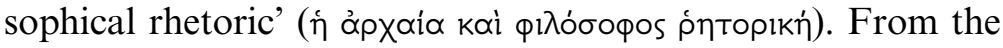
previous discussion, however, it seems clear that 'true philosophy' is a polemical term and intended to be opposed to some other, previous, conceptualizations of philosophy. What exactly Dionysius intended with this opposition we cannot know for sure, but it is highly plausible that Dionysius contrasts his notion of philosophy with that put forth by philosophical schools which laid primary emphasis on theoretical contemplation and presupposed theoretical foundation as the

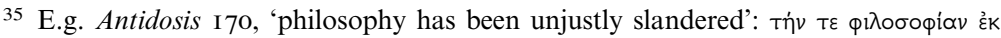

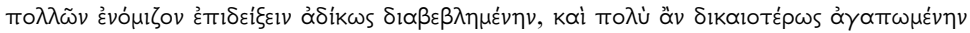

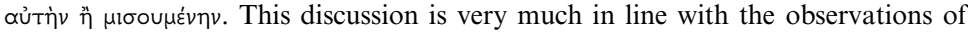
Hunter (20I2), I I8. 
basis for any form of action. Dionysius, who advocates in his critical works a view of judgements as having both rational and irrational components, ${ }^{36}$ must therefore regard this kind of (anti-theoretical) philosophy as 'more true' to human nature, as it also takes into account human actions that cannot be logically reasoned or accounted for. In this sense, Isocrates' denial of the possibility for human knowledge with its wider implications for any kind of theoretical activity could well be seen as parallel to, or an inspiration for, Dionysius' 'true' philosophy.

It has to be taken into account that Isocrates and his pupils were operating in a very different environment from that of Dionysius, and that the semantic fields of the notions 'philosophy' and 'philosopher' were more fluid and less theorized in fourth-century BCE Athens when compared to first-century BCE Rome. ${ }^{37}$ By Dionysius' time, philosophical schools had been running for about three hundred years, each making specific claims about philosophy and what it means to be a 'professional' philosopher. Moreover, often the direction and specific interests pursued in a philosophical school were determined by the lead 'professional' scholarch: e.g. with Arcesilaus the Academy became skeptic, with Antiochus of Ascalon the Academy became eclectic, Chrysippus developed Stoic logic and is famously claimed to be responsible for the existence of the Stoa, and so on. ${ }^{38}$ The notion of a 'philosopher' had thus become associated with a professional thinker who worked within a specific philosophical tradition and was in constant conversation with a rather narrow circle of similar-minded people. Despite their potentially conflicting positions, members of different philosophical schools would nevertheless call their

36 See more on this below.

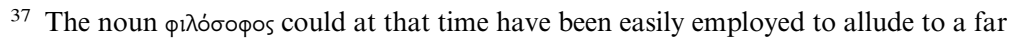
broader range of meanings (e.g. 'wise man', 'lover of wisdom' etc.) and Isocrates' use of this terminology, discussed above, is testament to this observation. A quick comparison with Plato, however, reveals that the latter uses the noun very frequently to refer to a 'professional' philosopher (e.g. Phaedo 63e ff., Theaetetus I64c9, Sophist 2 I6c6 etc.).

${ }^{38}$ For an overview of the contributions of various Hellenistic philosophers to the philosophical tradition, see Long (I986). 
opponents 'philosophers', because they share some basic understanding about the profession, about how philosophy is fundamentally done, and this was often a direct result of sharing philosophical authorities across schools (e.g. Socrates was considered a foundational figure for the Cynics, Stoics and Academics).

In his critical essays where Dionysius addresses Roman intellectuals, many of whom would have studied or been familiar with the philosophical schools, Dionysius is cautious and avoids going against the standard philosophical terminology. This is understandable: in order to be taken seriously as a teacher, he had to exhibit familiarity with the relevant terminology, especially on matters that were tangentially relevant but not directly the focus of his writing. Indeed, as his First letter to Ammaeus suggests, Dionysius was well aware of the prominent members of established philosophical schools, and was willing to engage with them on issues that concerned him. In such situations, Dionysius had to demonstrate himself as competent in current debates and capable of engaging in constructive conversation. This was not the appropriate place, in other words, to start questioning the meaning of philosophy itself. When, however, Dionysius discusses Isocrates and the philosophical underpinnings of his own views on rhetoric, he is clearly in a better position to offer a more provocative vision of the field and to challenge the existing philosophical establishment. And even in his essay on Isocrates, where he explicitly promotes 'true philosophy', he actually only implicitly goes against the standard philosophical tradition, ${ }^{39}$ for ultimately the aim of the whole project was to provide students with rhetorical models for imitation and not an extended debate about the true meaning and application of philosophy. Isocrates is singled out as offering philosophical perspective and inspiration for students of rhetoric, but a closer analysis of how to actually read Isocrates and interpret his work seems to

39 In I3.3 he makes a reference to Hieronymus the philosopher, thus indicating that he is very much comfortable, even in the essay on Isocrates, in applying the term philosophy in a traditional sense. 
fall unfortunately outside Dionysius' objectives. Elsewhere, when reviewing different orators and reflecting on the views of various other critics, Dionysius follows the widely shared and traditional sense of philosophers and makes no reference to 'true philosophy'.

Hence, where Dionysius operates as a literary critic, he makes a clear distinction between rhetoric and philosophy and their respective aims and methods. In fact, a clear example of Dionysius' distinct use of the notions rhetoric and philosophy is his First letter to Ammaeus (FLA), which explicitly contrasts both professions: the philosopher Aristotle and the orator Demosthenes. ${ }^{40}$ This is a fascinating and frustrating work at the same time: it raises important questions regarding the relationship between rhetoric and philosophy, but (even less than his essay on Isocrates) does not aim to discuss them more thoroughly and ends up being solely interested in establishing a strict chronology between the works of Aristotle and Demosthenes. ${ }^{4 \mathrm{I}}$ The first couple of chapters of FLA promise, however, something quite exciting: Dionysius finds the view that Demosthenes might have used Aristotle's Rhetoric to compose his speeches at first ridiculous, but realizing that this argument is brought forward by a respectable Peripatetic, ${ }^{42}$ he writes this letter to demonstrate the falsity of this account and prevent the philosopher from publishing his views (FLA I.23). Dionysius is worried that if this view becomes more widespread, people might start thinking that all the precepts of rhetoric are comprehended in the Peripatetic philosophy (2.3):

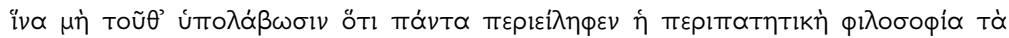

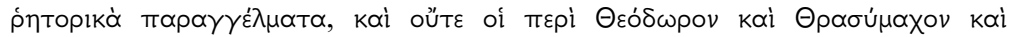

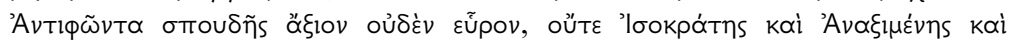

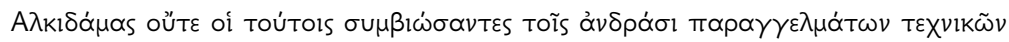

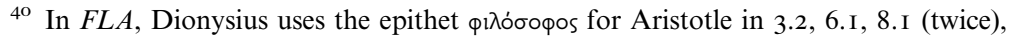
9.I, II.2, I2.I, I2.2, I2.4, I2.6; in 7.2 and the very last paragraph of the FLA he highlights a clear contrast between Aristotle the philosopher and Demosthenes the orator.

${ }^{4 I}$ Roberts (I90I), I6I-3 has summarized the letter, for example, in a chronological table.

${ }^{42}$ Wooten (I994), I 2 I-2 argues it might be Andronicus of Rhodes. 


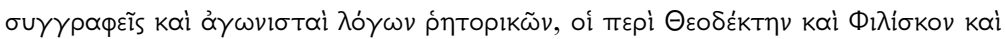

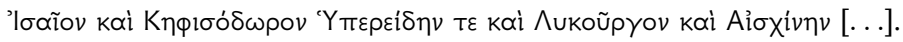

So that they would not suppose that all the precepts of rhetoric are comprehended in the Peripatetic philosophy, and that nothing important has been discovered by Theodorus, Thrasymachus, Antiphon and their associates; nor by Isocrates, Anaximenes, Alcidamas or those of their contemporaries who composed rhetorical handbooks and engaged in oratorical contests: Theodectes, Philiscus, Isaeus, Cephisodorus, Hyperides, Lycurgus and Aeschines [...].

In other words, the Peripatetic tradition might be an important source for rhetorical technique, but this is only one among many useful sources one could turn to. Even the best orators of the fourth century (e.g. Demosthenes) knew this and chose eclectically between various models (2.3) - a technique Dionysius recommends and highlights as the purpose of his writing the critical essays (Ant Or. 4).

Interestingly, however, Dionysius does not base his claims about the relationship between Demosthenes and Aristotle on their different views of the rhetorical art. Rather, Dionysius seems to suggest that while it is certain that Demosthenes could not have read Aristotle's Rhetoric, the latter could have based his Rhetoric on the speeches of Demosthenes and of other orators ( FLA I2). Even though Dionysius' extended discussion of the matter might initially suggest otherwise, it is not simply a matter of chronology, of who managed to write down their insights on rhetoric first. Rather, Dionysius might be making here a more general point about studying rhetoric: it does not suffice to read theoretical instructions about how to write/perform speeches, but rather it is important to explore the actual practice and study the performed speeches of orators, much like Demosthenes had to do. ${ }^{43}$ Aristotle's theoretical explorations, although helpful, can only go to a certain extent in helping the student of oratory; and even then, it is still necessary to become intimately acquainted with the actual speeches of those orators who are regarded as the best. In other words, there is something important to be learned from

43 Assuming that his alleged associations with Isocrates and Isaeus are accurate. 
mimesis that cannot be found in the theoretical discussions of the 'philosophers'. The letter is frustrating, however, because it seems to imply this interpretation, but does not explicitly state it. Why? Dionysius keeps constantly going back to various chronological evidence, bringing little proofs from Demosthenes and Aristotle's Rhetoric that would prove that the influence could not have been from the philosopher to the orator. It seems likely that the literary historian has taken over the literary critic at this point, and rather than fleshing out a more general account about why any such comparison between a theoretical text on rhetoric and actual speeches makes little sense, Dionysius continues to exhibit his command of the historical material.

The uselessness of philosophers for rhetorical instruction is also expressed in Dionysius' De compositio verborum (CV). There, Dionysius looks at Stoic philosophers as potentially useful sources for principles governing composition. ${ }^{44}$ This discussion is prefaced by a reference to Chrysippus, the famous head of the Stoa of the third century BCE, whose writings on (what may appear to be) similar topics demonstrate clearly to Dionysius that the Stoic is inept in arranging his compositions: 'of writers who have been judged worthy of renown or distinction, none has written treatises on logic with more precision, and none has published discourses which are worse specimens of composition' ${ }^{45}$ And Chrysippus is just one example, the tip of the iceberg. While admitting that Chrysippus approaches the topic from a strictly logical perspective, Dionysius is nevertheless eager to find out whether there is anything in Stoic examination of the topic that might be of use for someone interested in composition. He answers this, unsurprisingly, with the negative. Despite the similarity of the titles of their works ${ }^{46}$ and to

44 For a more in-depth discussion of Dionysius' relationship to Stoicism, especially in his $C V$, see de Jonge (2008). The present passage is analyzed at I08-II and 274-6.

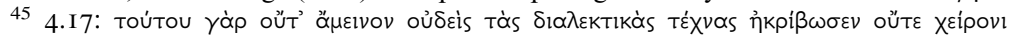

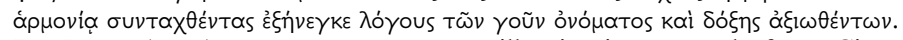

46 De Jonge (2008), 275 n. 98 quotes an illuminating example from Cicero's De oratore 2.6I, where Antonius expresses a similar frustration to Dionysius regarding the misleading book titles of (some) philosophical works. 
give an example Dionysius quotes the title of Chrysippus' work

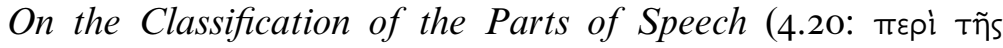

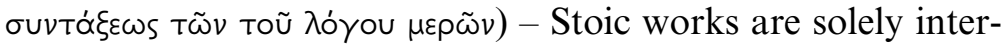
ested in logical investigations ${ }^{47}$ which examine categories of propositions, whether they are true or false, possible or impossible, admissible or variable, ambiguous and so forth (4.2 I). Dionysius concludes that they 'contribute nothing helpful or useful to civil oratory, at least as far as the attractiveness and beauty of style are concerned, which should be the aim of composition'. ${ }^{48}$ In other words, Stoic philosophers, even when they discuss a topic of interest to those concerned with composition, focus solely on the logical and highly abstract side of the question and, in so doing, they fail to say anything practically relevant on the subject. In contrast to the Stoic philosophers

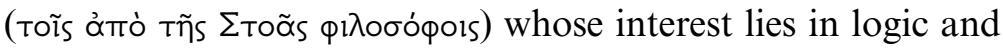
theoretical speculations, Dionysius is explicitly associating him-

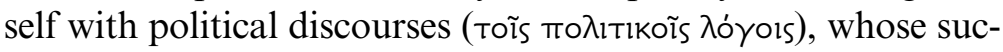
cess in composition is measured in terms of pleasure and beauty of style. Here we see, then, the opposition between philosophy as a purely theoretical pursuit and Dionysius' practice-driven conception of politikoi logoi fully set out. ${ }^{49}$

Yet, while distancing himself from 'theoretical philosophers', Dionysius commends philosophers' critical attitude to their peers and authorities, and he proposes to also employ their constructive approach to literary criticism. In his essay on Thucydides, Dionysius spends some time explaining his motivations behind writing an extended critique of Thucydides.

47 This is problematic and no Stoic would agree with this characterization.

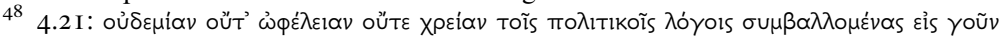

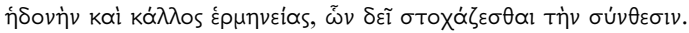

49 Goudriaan's (I989) discussion of Dionysius' politikos logos is perhaps the most idiosyncratic: he traces the ancestor for Dionysius' usage of the notion to Plato's Laws and argues that it is Plato's system of musical education that underlies Dionysius' description of the functioning of style in the politikos logos. Goudriaan admits, however, that Dionysius makes a particular use of this Platonic model and calls it 'a kind of reduced transcendentalism' (694). He furthermore seems to associate Dionysius' classicism with Plato. In the light of the present discussion here and Dionysius' explicit preference of Isocrates over the metaphysics of Plato, Goudriaan's suggestion appears extremely far-fetched and not sufficiently supported by what Dionysius actually says. 
He already assumes that his views will be met with hostility by some of the readers, and evokes philosophers as examples of constructive criticism and of a method of critique that, instead of stifling the discussion, provokes a further search for truth: Aristotle, Dionysius says, criticized his teacher Plato, who in turn tried to prove his predecessors Parmenides, Protagoras and Zeno wrong (3.4). As Dionysius remarks, nobody criticizes these authors for disagreeing with their predecessors or previous authorities, 'for it is recognized that the goal of philosophical studies is the discovery of truth by which the purpose of life is revealed'. ${ }^{\circ}$ But if this is the case with philosophers and it is widely agreed that the search for truth might in time prove previous proponents wrong, 'why should one censure those who have taken up describing an author's individual style when they do not ascribe to it all the qualities allowed to it by earlier critics, even those which it does not possess?' ${ }^{\text {I }}$ Despite the differences in topic, Dionysius assumes that literary critics share the same commitment to truth that characterizes philosophers, and thus they should also adopt the same method of constructive criticism that has been accepted for, and was widely used by, the philosophers. ${ }^{52}$

When he proposes that literary critics 'borrow' a useful method from the philosophers, Dionysius clearly sides with the critics and not with philosophers. At the same time, the beginning of the essay contains perhaps more references to philosophy and to his own engagement with it than what we see elsewhere in Dionysius' work. He casually mentions that he had in fact written a polemical work on political philosophy

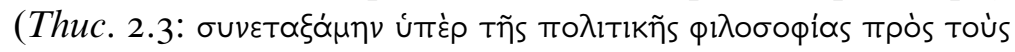

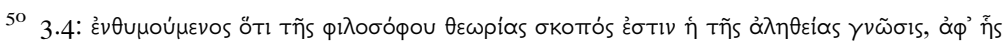

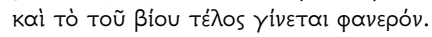

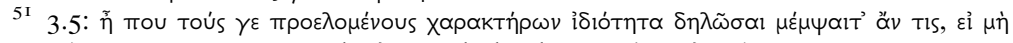

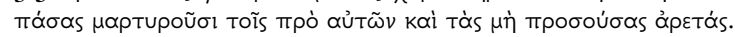

52 There is of course a significant difference that Dionysius neglects: contrary to those philosophers who critique their predecessors who tackled the same topics as they do, what Dionysius will be criticizing in Thucydides or Plato, for example, is not really their contributions to their respective sciences (history or philosophy), but something that had not been identified as their primary goal - style and effective use of language. 


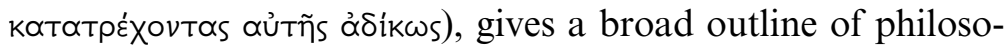
phy, its aims and methods, and finally offers a definition of the

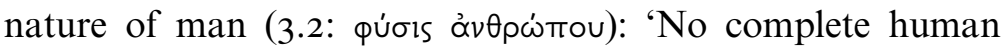
being has the self-sufficiency to be infallible in either word or deed: the best is the man who hits the mark most often, and misses it least. ${ }^{53}$ Even though this definition is offered as a justification for the following close analysis of Thucydides' style and simply suggests that everybody makes mistakes, including Thucydides, the tone and underlying idea are relevant to what Dionysius elsewhere says about philosophy.

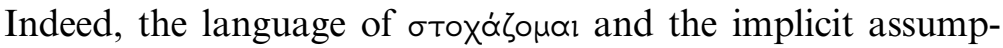
tion of this passage that there is no abstract universal knowledge that would be attainable for human beings, which would enable them to attain truth or knowledge through contemplation and help them avoid making mistakes, has strong resemblances to the Isocratean concept of (the unattainability of ) knowledge and the consequent possibilities for the pursuit of philosophy. ${ }^{54}$ Also, it is probably no coincidence that Dionysius' views on philosophy emerge in the two essays Isocrates and Thucydides, for it is in the first where he establishes the philosophical underpinnings of the rhetorical tradition, and in the second where he places his own critical activity, both in the rhetorical and historical writings, under close scrutiny. Self-criticism and the discourse of apology is used to a powerful effect in Isocrates' Antidosis, and the beginning of Dionysius' Thucydides is in its spirit very similar to that Isocratean discourse. Here too Dionysius refers to his potentially hostile audience (2.2), offers a brief overview of his critical activity (2.3) and uses the language of deciding (2.4: kpivelv), as in a court case.

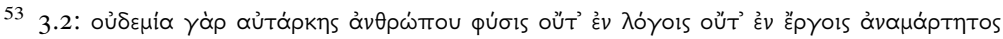

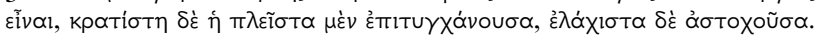

54 Isocrates uses this notion several times in his Panathenaicus (30, 26I, 27I), but also

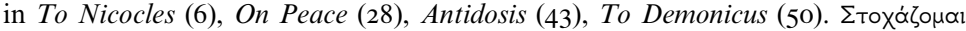
and its cognates also play a central role in identifying the valid method in rhetorical discourse in Aristotle's Rhetoric (e.g. I355a I 7, I36ob5, I362a I5, I395bio, I406a I6, I4IOb35, I4I5b28, I4I9bi6). 
True Rhetoric, True Philosophy and True Isocrates

This divide between theoretical and practical knowledge that seems to distance Dionysius from the philosophers, and at the same time enables him to label his own intellectual pursuit as philosophy in the wake of Isocrates, is closely connected to his views about critical judgement. Dionysius famously claims in a passage of his essay on Thucydides that there are two kinds of literary judgement, one that everyone can access and make use of, since it is based on irrational sensations and feelings that literary works arouse (4.3: $\tau \tilde{\omega} \nu ~ \tau \varepsilon ~ \delta i$

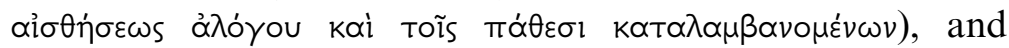
another that is characterized as expert knowledge and theoretical. The former comprises, in Dionysius' words, 'the faculties which all forms of art aim to stimulate and are the reason for

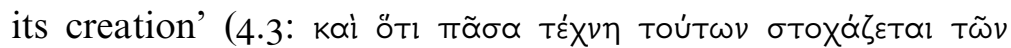

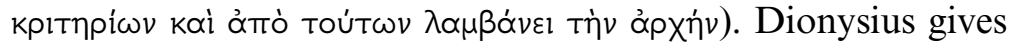
an example of this kind of sensation-based irrational judgement in action when he describes the impact of Isocrates' discourses on himself (Demosthenes 22.I):

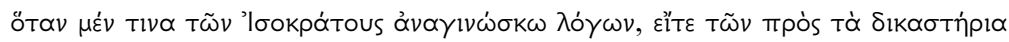

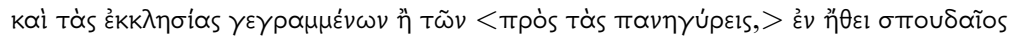

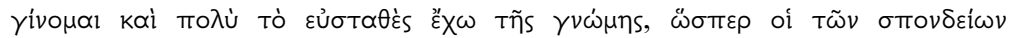

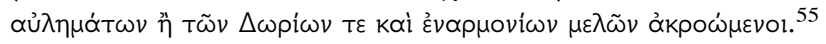

Whenever I read a speech of Isocrates, whether it be forensic, political (or epideictic), I become serious and feel a great tranquillity of mind, like those listening to libation-music played on reed-pipes or to Dorian or enharmonic melodies.

Dionysius then brings in a comparison with Demosthenes, but what is more relevant for the present discussion is that he prefaces these comparisons with a brief suggestion that the feelings he describes are not uniquely his own, but rather

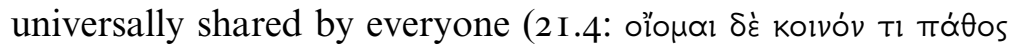

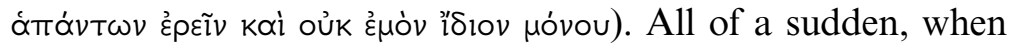
describing a universal mátos, this irrational sensation which Dionysius outlined in Thucydides starts looking less irrational

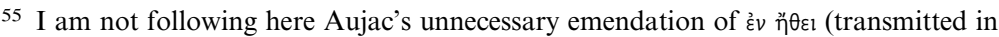
the manuscripts) to $\tau \dot{\alpha} \ddot{\eta} \theta \eta$, despite the parallel he cites from Isocrates 4.3 ( $\dot{\alpha} \lambda \lambda \dot{\alpha}$ k $\alpha \dot{\alpha}$

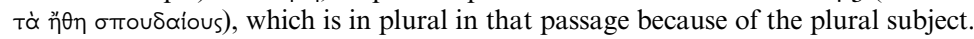




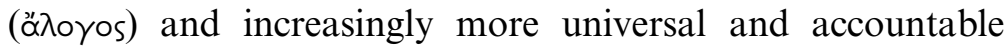

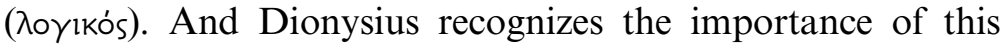
shift, for a good critic and teacher is, presumably, someone who has both trained his (irrational) senses and is up to date with the best means of explanation. ${ }^{56}$ It seems, however, that there is no qualitative difference between the layman operating

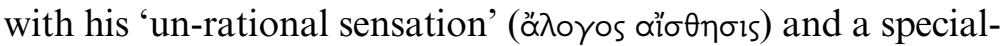

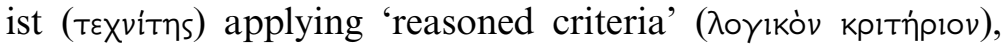
but merely a quantitative one: the critic will have consciously cultivated his senses and abilities to describe, write down and explain the aesthetic effects of prose for students. Here again, Dionysius seems to reject pure abstract theoretical rules (like in a textbook) that can be simply imposed on oratorical practice; instead, an expert is someone who has accumulated these sensations and organized them in groups of patterns himself (much like Dionysius shows us how to do in his critical essays) that might be helpful in guiding the sensations of the students, without trying to provide a metaphysical or abstract explanation of these phenomena. In other words, just as Isocrates said (Helen 5): of important things likely conjecture is preferable to exact knowledge of the useless.

Thus far it has been emphasized that Dionysius is deeply inspired by Isocrates' politico-philosophical program. Yet, when Dionysius decides to fashion his discourse as a politikos $\log o s$, and in so doing consciously invokes the Isocratean model, he also appears to take precautions in order to make sure that he will not be taken for yet another Isocratean stylist. Isocrates and his followers had long attracted negative attention from critics and Dionysius makes several references to this group in his essays: in $C V$ (I9.I3) he refers more generally to the style of composition used by Isocrates and his followers

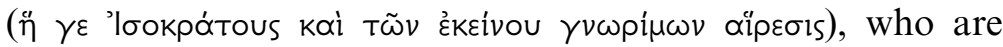
introduced as an example of a rather unsuccessful application of the principle of variation and change in their compositions. In Isaeus (I9.4), Dionysius gives a list of famous pupils of

${ }^{56}$ A helpful discussion of Dionysius' use of the two evaluative criteria, tò ä $\lambda$ oyov tĩs

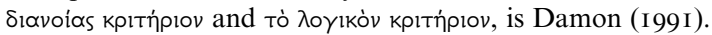


Isocrates who cannot, however, be compared with the genius of Isocrates. ${ }^{57}$ Indeed, there are clear tensions between the originator and the copyist or imitator that Dionysius hints at in the last quotation, and these are further explored in his Dinarchus. There Dionysius is primarily interested in establishing useful guidelines for differentiating between authors and confirming or rejecting authorship of ancient writings. The main focus is on Dinarchus, whose varied and heterogeneous style is compared to the imitators of Isocrates who also display many similarities but also important differences from the works of Isocrates. ${ }^{58}$ In a later passage (8), Dionysius discloses explicitly the pitfalls of closely imitating an author. Examples are drawn more generally from the followers of Plato, Thucydides, Hyperides, Isocrates and Demosthenes, but we will focus here on the Isocrateans. The trouble with the Isocrateans, and in particular with their style, is that it became

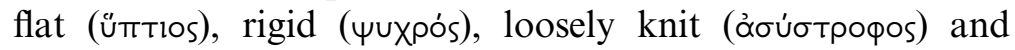

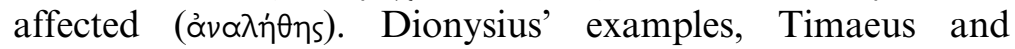
Psaon, are historians (a third name mentioned, Sosigenes, is otherwise unknown), whose Isocratean style Dionysius strongly disapproves of. As a historian, as well as a literary critic and a rhetorician, Dionysius goes to quite a length to return to this topic in various essays and make clear that he is not one of the 'Isocratean-type' historians, or a promoter of their interpretation of the importance of Isocrates. In other words, by overtly distancing himself from previous proponents of Isocrates, Dionysius is careful to make sure that his treatment of the famous educator and rhetorician breaks new ground in the overall appreciation of Isocrates, and establishes him as an authority in the philosophical sphere of rhetoric.

It is by now clear that Plato's Phaedrus lies in important ways behind Dionysius' assessment of Lysias and Isocrates in his critical essays and, more generally, that this dialogue

57 The superiority of Isocrates over his imitators and followers is also explicitly mentioned in $C V$ I9.I3.

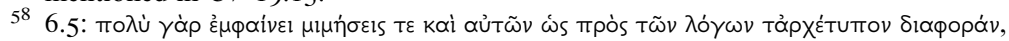

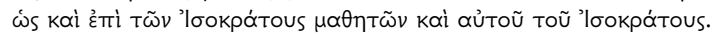


deeply informs Dionysius' treatment of the ancient rhetorical tradition. The portrayal of an Isocrates with lots of philosophical potential, as contrasted to the clever and persuasive Lysias, is obviously indebted to the Phaedrus. While Plato's discussion of the orators is also ironical or even outright critical, Dionysius picks up none of the criticisms of the two and has no ear for Socratic irony. Is Dionysius simply misreading the dialogue, or could we see here Dionysius' more critical engagement with Plato? The latter option seems more plausible. Dionysius' systematic reinterpretation of Isocrates and Lysias, combined with his ambivalent attitude to Plato (especially as a critic of style) and his ambition to put together a comprehensive account of the rhetorical tradition, all suggests that Dionysius probably entertained a competitive attitude to Plato. While the latter had had a strong impact on the reception of Lysias and Isocrates, Dionysius was to counterbalance that with his own interpretation of the two orators as constitutive pillars of the rhetorical art: Lysias as a legitimate model for style and Isocrates as the path-breaking visionary in education and philosophy. In other words, Dionysius not only follows and promotes Isocrates' philosophy, as has been suggested many times before, but he creates the image of a 'true Isocrates' that he then brilliantly casts as an underlying philosophical feature of his own program. In some circles, Dionysius' interpretation of the two rhetors prevails, in others, that of Plato. For us, however, all these four writers present the sine qua non of the ancient rhetorical tradition. 